\title{
LARP4B wt Allele
}

National Cancer Institute

\section{Source}

National Cancer Institute. LARP4B wt Allele. NCI Thesaurus. Code C143065.

Human LARP4B wild-type allele is located in the vicinity of 10p15.3 and is approximately $181 \mathrm{~kb}$ in length. This allele, which encodes La-related protein 4B, plays a role in translation. Mutations in the gene may be associated with acute myeloid leukemia, glioma and colorectal cancer. 